Available online at: https://proceeding.researchsynergypress.com/index.php/cpmhs/index

RSF Conference Series: Medical and Health Science

e-ISSN (to be processed) / p-ISSN (to be processed)

Volume 1 Number 1 (2021): 97-105

\title{
Factors Influenced Healthcare Service Delivery During COVID-19 Pandemic: A Case Study in Cicalengka, Indonesia
}

\author{
Eka Nurhayati' ${ }^{1}$, Dika Ananda Elyani' ${ }^{2}$, Yanti Fadillah ${ }^{3}$ \\ ${ }^{1}$ Public Health Department, Faculty of Medicine, Universitas Islam Bandung, Indonesia \\ ${ }^{2}$ Faculty of Medicine, Universitas Islam Bandung, Indonesia \\ ${ }^{3}$ Puskemas Cicalengka, Bandung District, Indonesia
}

\begin{abstract}
Since the enactment of the restriction in 2020, Puskesmas Cicalengka has been faced numerous healthcare delivery problems, which led to the failure of achieving the target of the healthcare program. It is important to identify the factors which caused the healthcare problems to compose a plan for years to come. Identification can be accomplished using a logic model framework consisting of input, process, output, and environment. This study was conducted to identify the input factors that play the roles in healthcare service delivery output in Puskesmas Cicalengka during the COVID-19 pandemic in 2020. This study was conducted as a qualitative study using a case study design. The study was done by analyzing related documents, observing and interviewing staff. Data was collected in March 2021. The result shows that Puskesmas was once closed in April 2020 due to the pandemic. In May 2020, Puskesmas reopened and started to provide healthcare services by following the new regulation from the Ministry of Health. The input factors which affected healthcare delivery in Puskesmas Cicalengka during the pandemic of COVID19 in 2020 were man, money, material, methods, minutes, and information. Machine was the only factor that did not affect healthcare delivery since it was in good condition. Further research must be completed with quantitative research to reach a comprehensive point of view.
\end{abstract}

Keywords: COVID-19, healthcare services, input factors, pandemic, Puskesmas

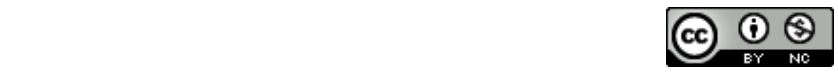

This is an open access article under the CC-BY-NC license

\section{INTRODUCTION}

Coronavirus disease 2019 (COVID-19) has been declared as a pandemic by World Health Organization (WHO) in 30 Januari 2020 (Sohrabi, et al., 2020). In Indonesia, the first case of COVID-19 was identified in March 2020 then the incidence has been increased over time. Since March 2020, the Indonesian Government has enforced social restrictions on a large scale or called Pembatasan Sosial Berskala Besar (PSBB). This enactment caused restrictions on almost all activities of the community, including healthcare delivery (Kementrian Kesehatan Republik Indonesia, 2020).

Primary public health centres in Indonesia, called Pusat Kesehatan Masyarakat or Puskesmas, play the role as the frontline in healthcare delivery (Kementrian Kesehatan Republik Indonesia, 2019). In the era of the COVID-19 pandemic, the task of Puskesmas has been doubling. Currently, COVID-19 is the priority, but Puskesmas still have to deliver high-quality healthcare to the community.

Puskesmas Cicalengka is one of the public health centers located in Bandung, West Java, Indonesia. It is categorized as an urban public health care center since it is located near the capital of the district. It has six villages under its territory and has 66.067 people in the community (Puskesmas Cicalengka, 2020). Since the enactment of the restriction in 2020, Puskesmas Cicalengka has been faced numerous healthcare Corresponding author Eka Nurhayati, nurhayatieka1@gmail.com; Dika Ananda Elyani, anandaeldika@gmail.com DOI: (to be processed) 
delivery problems, which led to the failure of achieving the target of the healthcare program. Based on the annual report in 2020, the healthcare programs output which did not achieve the target are:

1. Maternal and Child Healthcare program, especially in the labor assistance by health workforce. The gap between the target and achievement was -2,11\%;

2. Health promotion program, especially health education for villages cadres. The gap was $-13,97 \%$;

3. Nutrition health program. Almost all activities in this program had failed in achieving targets, but the biggest gap percentage was the delivery of iron tablets for teenage girls aged 12-18 years in school with a gap of $-88,95 \%$.

4. Environmental health program, especially in monitoring of drinking water quality with the gap of $63,5 \%$.

5. Disease prevention program, there are three activities which had the highest gap reached $-95 \%$. These activities were the coverage of the immunization of diphtheria-tetanus (Dt), tetanusdiphtheria (Td), and mumps rubella (MR) for children of school age.

6. Individual Health Services Program, there was a gap of $-45,75 \%$ in the coverage of dental outpatient visits and $-35,67 \%$ in the coverage of emergency room visits.

Based on this data, it is important to identify the factors which caused the healthcare problems mentioned above. Identification can be accomplished using the logic model framework. The logic model framework identified factors from input and process which influenced intended results. Thus, this study was conducted to identify the input factors that play the roles in healthcare service delivery output in Puskesmas Cicalengka during the COVID-19 pandemic in 2020.

\section{LITERATURE REVIEW}

\section{The Logic Model}

The logic model framework is defined as a systematic and visual tool to present and share the understanding of the relationships among available resources needed to operate programs/projects/activities that are planned and the change of the expected change in results or output (W.K. Kellogg Foundation, 2004). Logic models have been used to evaluate and develop a variety of programs, including health programs in all over countries in the world. The logic model was developed by Green and Kreuter (McAndrew \& Kaskutas, 2020). Kellogg Foundation then released Logic Model Development Guide in 2004 (W.K. Kellogg Foundation, 2004).

The purposes of the Logic model are (Ebenso et al., 2019; Smith et al., 2020):

1. clarifying objectives, goals, and gaps;

The logic model can help implementers to make clear objectives and goals. It also helps evaluators to identified gaps in programs. Thus they can collaborate to clarify, modify or specify resources and activities.

2. assessing of feasibility of programs at an early stage;

Logic models help implementers and evaluators to identify available resources at an early stage while the program is being developed. Implementers can make a better plan with this kind of information and has a chance of achieving desired outcomes.

3. Monitoring progress of implementation stage;

The logic model facilitates implementers and evaluators to monitor how the program and/or all determinants or factors evolve over its life span by providing a systematical and visual framework. The logic model may help to see the adequacy of resources in input and the running of activities according to plan. 
4. developing method for evaluation;

The logic model helps the evaluator to identify factors of all elements that are vital for the program. Developing and designing data collection using a logic model can help examination and testing the program to provide a reasonable explanation for answering assumptions or hypothesized mechanisms.

5. Dissemination and knowledge building.

The logic model helps stakeholders or decision-makers to make the right choice by providing an efficient way to assess the applicability and generalizability of the program to other settings of the community.

The components of the logic model, according to WK Kellog Foundation (2004) divided into two, which are planned work and intended results. Image 1 describes the basic logic model mentioned by WK Kellog Foundation (2004).

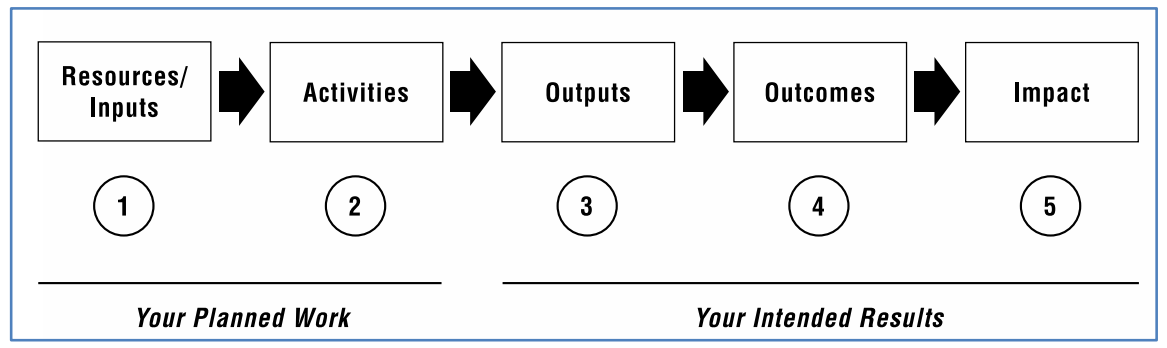

Figure 1. The Basic Logic Model (W.K. Kellogg Foundation, 2004)

Planned work consists of input and process. Inputs are available resources that include the human, financial, material, organizational, and community resources that can be utilized doing the work or activities (W.K. Kellogg Foundation, 2004). Inputs can also be an organizational commitment to engagement and training that is provided for staff (Sofaer, 2019). Program activities refer to processes, events, and actions as an intentional part of the program implementation to reach the desired results or outputs (W.K. Kellogg Foundation, 2004).

Intended results consist of outputs, outcomes, and impact. Outputs are the direct products of process or program activities. Outcomes are the specific changes in knowledge, attitude, behavior, skills, status, and level of functioning among the community or program participant.

\section{Health Care Service Delivery in Pandemic Era}

Health care service delivery is being challenged in the Covid-19 pandemic era. As demands on the prevention and management of Covid-19 increases, society also demands health care facilities to maintain health care routine service delivery. Health care facilities are demanded to quickly adapt in order to ensure access for society in health care both in routine service and Covid-19 service (World Health Organization, 2020).

World Health Organization (WHO) recommend governments establish incident management teams (IMT). The member of IMT should be focal points for essential health services. This focal point works as a coordinator who rearranges human, financial, and material resources and mobilizes other resources, especially during the early phase of the pandemic. Other actions that governments should do according to WHO is to establish a chain command and coordination system, mechanism, and protocols to deliver the health care, monitoring mechanism, and maintaining coordination between stakeholders, especially finance and health (World Health Organization, 2020). 
During the Covid-19 pandemic era, although services for Covid-19 are prioritized, some of the other routines can not be underestimated. The other high-priority categories are (World Health Organization, 2020):

1. Prevention and treatment for a communicable disease such as immunizations;

2. Reproductive health care services such as pregnancy and childbirth;

3. Availability of medications, equipment, and supplies;

4. Critical facility-based therapies;

5. Emergency health conditions;

6. Auxiliary services, such as laboratory, blood donors, or imaging.

Health care facilities must optimize service delivery by rearranging resources. Some steps recommend by WHO are (World Health Organization, 2020):

1. Optimize health workforce capacity;

2. Maintain the availability of essential medications, equipment, and supplies;

3. Remove financial barriers;

4. Strengthen communication strategies;

5. Establish safe and effective patient flow;

6. Strengthen the evaluation and monitoring of health care services;

7. Use digital platforms as an option to support health care service delivery.

\section{RESEARCH METHODOLOGY}

This study was conducted as a qualitative study using a case study design. The case study design was chosen as a case study can help to build understanding on how Puskesmas have coped with challenging situations and help to obtain information through a brief of time. The study was done by analyzing related documents such as The Annual Report of Puskesmas Cicalengka Year 2020 and the essential program data, observing and interviewing staff. The inclusion criteria for staff interviewed was: have access to Puskesmas Cicalengka resources and have worked in Puskesmas Cicalengka before and during the pandemic; thus, they can compare both situations. Data was collected in March 2021. Analysis was carried out by comparing the input and process factors in the Puskesmas with the standards imposed by the Ministry of Health. The regulation which was used as standards were The Regulation of Minister of Health No. 43 Year 2019 about Puskesmas and The Regulation of Minister of Health No. 44 Year 2016 about Puskesmas Management Guidelines. Data were analyzed using Microsoft Word. Validity and reliability were done by triangulation. Data is presented in a comparison table to simplify the identification.

\section{FINDINGS AND DISCUSSION}

Based on the interviews, it is known that Puskesmas was once closed in April 2020 due to the pandemic. In May 2020, Puskesmas reopened and started to provide healthcare services by following the new regulation from the Ministry of Health. The staff must use personal protective equipment and follow strict health protocols. The number of visits has been reduced significantly, with a maximum of 20 visitors each day. Before the pandemic, the visit could reach more than 100 patients.

The pandemic also has changed the healthcare services flow. Before a pandemic, patients can go straight into the building and get a queue ticket until they are finally called. After a pandemic, patients must wash their hands first, temperature checked, get in line then enter the building. They also must keep a certain distance from each other to prevent transmission. 
This incident was not only happened in Puskesmas Cicalengka. Other research in Puskesmas Ranotana Weru revealed that the Puskesmas has also enforced new health protocols such as washing hands, checking body temperature, advanced anamnesis, and physical examinations and physical distancing. The number of visitors also decreased significantly (Pangoempia et al., 2021).

Analysis of input factors which was conducted in this research is described in Table 1. The input factors include Man, Money, Materials, Machines, Methods, Minute, and Information.

Table 1. Gap Analysis of Healthcare Services Delivery in Puskesmas Cicalengka

\begin{tabular}{|c|c|c|}
\hline Variable & $\begin{array}{l}\text { Standard } \\
\text { (Kementrian Kesehatan } \\
\text { Republik Indonesia, } \\
\text { 2019; Kementrian } \\
\text { Kesehatan Republik } \\
\text { Indonesia, 2016) } \\
\end{array}$ & Results \\
\hline Man & $\begin{array}{l}\text { Number of Medical Staffs in } \\
\text { Urban Puskesmas } \\
\text { - } \quad \text { Doctor: } 2 \\
\text { - } \text { Dentist: } 1 \\
\text { - Nurse: } 8 \\
\text { - } \text { Midwife: } 7\end{array}$ & $\begin{array}{l}\text { Number of Medical Staffs in } \\
\text { Puskesmas Cicalengka } \\
\bullet \quad \text { Doctor: } 7 \\
\text { • } \quad \text { Dentist: } 2 \\
\text { The numbe: } 15 \\
\text { who had been confirmed with } \\
\text { CoVID at the Puskesmas } \\
\text { Cicalengka } \\
\text { - } \quad \text { Doctor: } 1 \text { person } \\
\text { - } \quad \text { Nurse: } 3 \text { persons } \\
\text { - } \quad \text { Midwife: } 1 \text { person } \\
\text { Number of Medical staff who } \\
\text { were conducting self-isolation } \\
\text { due to CoVID-19 } \\
\text { Nurse: } 7 \text { persons } \\
\text { Conclusion } \\
\text { Even though the quantity of the } \\
\text { staff was exceeding the standard } \\
\text { but "puskesmas" had } \\
\text { experienced a crisis of medical } \\
\text { staff due to infection of COVID- } \\
\text { 19. }\end{array}$ \\
\hline Money & $\begin{array}{l}\text { Source: } \\
\text { - State Revenue and } \\
\text { Expenditure Budget } \\
\text { - } \quad \text { Regional Revenue and } \\
\text { Expenditure } \\
\text { Budget } \\
\text { - Other Sources } \\
\text { Allocation: } \\
\text { - There is no standard for } \\
\text { allocation, but it's } \\
\text { tailored to the needs of } \\
\text { healthcare programs. }\end{array}$ & $\begin{array}{l}\text { Source: } \\
\text { - State Revenue and } \\
\text { Expenditure Budget } \\
\text { - } \quad \text { Regional Revenue and } \\
\text { Expenditure Budget } \\
\text { - Other Sources: Regional } \\
\text { Public Service Agency } \\
\text { budget } \\
\text { Allocation: }\end{array}$ \\
\hline
\end{tabular}




\begin{tabular}{lll}
\hline Variable & Standard & Results \\
& (Kementrian Kesehatan & \\
& Republik Indonesia, & \\
& 2019; Kementrian & \\
& Kesehatan Republik & \\
& Indonesia, 2016) & \\
\hline
\end{tabular}

Adapted to the programs, but there was no budget plan related to COVID-19.

\section{Conclusion:}

Puskesmas must allocate some funds related to new health protocols and procedures.

\begin{tabular}{|c|c|c|}
\hline Material & $\begin{array}{l}\text { Complete for any kind of } \\
\text { health examination in the } \\
\text { primary health center }\end{array}$ & $\begin{array}{l}\text { Needs: } \\
\text { Tools for antigen swabs and } \\
\text { disposable personal protective } \\
\text { equipment for implementing } \\
\text { new health protocols related to } \\
\text { COVID-19, such as sinks, } \\
\text { disinfectant solutions. } \\
\text { Conclusion: } \\
\text { Limitation on materials related } \\
\text { to new health protocols and } \\
\text { procedures. }\end{array}$ \\
\hline Machine & $\begin{array}{l}\text { Ambulance, the quantity was } \\
\text { not mentioned. }\end{array}$ & $\begin{array}{l}\text { Availability: } \\
\text { Two units of the ambulance are } \\
\text { in good condition. } \\
\text { Conclusion: } \\
\text { There was no resistance related } \\
\text { to machine }\end{array}$ \\
\hline \multirow[t]{2}{*}{ Methods } & $\begin{array}{l}\text { Healthcare delivery for } \\
\text { individuals, families, and } \\
\text { communities with minimum } \\
\text { personal protective } \\
\text { equipment. }\end{array}$ & $\begin{array}{l}\text { Healthcare delivery for } \\
\text { individuals, families, and } \\
\text { communities with optimum } \\
\text { disposable personal protective } \\
\text { equipment. All methods } \\
\text { implemented outdoor had been } \\
\text { restricted. } \\
\text { The flow for patient services is } \\
\text { modified. }\end{array}$ \\
\hline & & $\begin{array}{l}\text { Conclusion: } \\
\text { Several methods have been } \\
\text { changed. }\end{array}$ \\
\hline Minutes & $\begin{array}{l}\text { The quantity of time allocated } \\
\text { to programs was not } \\
\text { mentioned, but it was tailored } \\
\text { to the need of the programs }\end{array}$ & $\begin{array}{l}\text { The operating hours have been } \\
\text { reduced, especially for outdoor } \\
\text { activities. More time had been } \\
\text { allocated for COVID-19 related } \\
\text { activities. }\end{array}$ \\
\hline
\end{tabular}




\begin{tabular}{ll}
\hline Variable & Results \\
\hline $\begin{array}{l}\text { Standard } \\
\text { (Kementrian Kesehatan } \\
\text { 2019; Kementrian } \\
\text { Kesehatan Republik } \\
\text { Indonesia, 2016) }\end{array}$ & $\begin{array}{l}\text { Conclusion: } \\
\text { Puskesmas had a shortage of } \\
\text { time for delivering healthcare } \\
\text { services. }\end{array}$ \\
\hline Anformation & $\begin{array}{l}\text { Needs: } \\
\text { Information related to COVID-19 } \\
\text { incidence and its impact on the } \\
\text { resource }\end{array}$ \\
& $\begin{array}{l}\text { community } \\
\text { Conclusion: }\end{array}$ \\
& $\begin{array}{l}\text { Puskesmas must collect data } \\
\text { from the community, which takes } \\
\text { more resources. }\end{array}$ \\
\hline
\end{tabular}

Based on Table 1, it is shown that the input factors which affected healthcare delivery in Puskesmas Cicalengka during the pandemic of COVID-19 were man, money, material, methods, minutes, and information. Machine was the only factor that did not affect healthcare delivery since it was in good condition. This result showed that the resources are not adequately supporting the output.

As mentioned above, to maintain healthcare services delivery, every healthcare facility must rearrange resources. In this case, Puskesmas Cicalengka has not succeeded in rearranging man, money, material, methods, minutes, and information. Some of these problems were predictable and should be offset through some strategies. Due to a shortage of time, it is difficult to take action rapidly.

Research in Uganda conducted by Kamulegeya et al. revealed that health services during the Covid19 pandemic could be delivered using digital health such as telehealth and telemedicine. The use of telehealth modalities has helped to reach society while maintaining social distance. Resources such as man, material, method, and minutes can be solved by the use of digital technologies (Kamulegeya et al., 2020). Programs that were not included in high priority, such as health promotion and environmental health, can be delivered through a digital platform. The health workforce does not need to be face to face with patients; even the staff who are quarantined can also participate from home.

Digital technologies also give an opportunity for health care facilities to establish call centers, digital surveillance systems, and health information dissemination (Kamulegeya et al., 2020). It would help healthcare facilities to collect or disseminate data from and to society safer and easier.

However, the use of digital health has limitations. First, the staff and society must have a high level of technology literacy as these kinds of technologies use computer-based applications and social media. Second, a geographical limitation can cause instability internet connection. Third, impact on cost or finance to provide the tools needed.

Based on Jazieh and Kozlakidis, the pandemic has become a transformation catalyst in healthcare delivery. Other than telehealth, governance in all sectors must fulfill the need for funding, research, and development, the development of regulations and guidelines, and establish monitoring and evaluation mechanisms (Jazieh \& Kozlakidis, 2020). In the case of Puskesmas Cicalengka, it is important for the Head of Puskesmas as the top manager to have good governance and rearrange the list of priority of resources. 
The Head of the Puskesmas must realize that leadership will help to organize institutions in such a short period of time.

\section{CONCLUSION AND FURTHER RESEARCH}

The input factors which affected healthcare delivery in Puskesmas Cicalengka during the pandemic of COVID-19 in 2020 were man, money, material, methods, minutes, and information. These factors were predictable and should be offset through some strategies. The Head of the Puskesmas is responsible for developing these strategies in order to maintain healthcare service delivery related to Covid-19 while still deliver routine healthcare as society demands. Good governance is important in decision-making in a short time to rearrange resources. It is also important to consider telehealth as one of the options to deliver health care services in the pandemic era. Further research must be completed with quantitative research to reach a comprehensive point of view.

\section{REFERENCES}

Ebenso, B. et al., 2019. Dealing with Context in Logic Model Development: Reflections from A Realist Evaluation of A Community Health Care Programme in Nigeria. Evaluation and Program Planning, Volume LXXIII, pp. 97-110.

Jazieh, A. R. \& Kozlakidis, Z., 2020. Healthcare Transformation in the-Post Coronavirus Pandemic Era. Frontiers in Medicine, Volume VII, pp. 1-6.

Kamulegeya, L. H., Bwanika, J. M., Musinguzi, D. \& Bakibinga, P., 2020. Continuity of Health Service Delivery during the COVID-19 Pandemic: the Role of Digital Health Technologies in Uganda. Pan African Medical Journal, XXXV(2), pp. 1-4.

Kementrian Kesehatan Republik Indonesia , 2016. Peraturan Menteri Kesehatan Nomor 44 Tahun 2016 Tentang Pedoman Manajemen Puskesmas. Jakarta: s.n.

Kementrian Kesehatan Republik Indonesia, 2019. Peraturan Menteri Kesehatan Nomor 43 Tahun 2019 Tentang Pusat Kesehatan Masyarakat. Jakarta: s.n.

Kementrian Kesehatan Republik Indonesia, 2020. Pedoman Pencegahan dan Pengendalian Coronavirus Disease (Covid-19). Jakarta: s.n.

McAndrew, R. \& Kaskutas, V., 2020. A Logic Model for Planning, Implementing and Evaluating a Student-Run Free Clinic. Journal of Student-Run Clinics, VI(1), pp. 1-10.

Pangoempia, S. J., Korompis, G. E. \& Rumayar, A. A., 2021. Analisis Pengaruh Pandemi Covid19 Terhadap Pelayanan Kesehatan di Puskesmas Ranotana Weru dan Puskesmas Teling Atas Kota Manado. Kesmas, Volume X, pp. 1-10.

Puskesmas Cicalengka, 2020. Laporan Tahunan. Bandung: s.n.

Smith, J. D., Li, D. H. \& Rafferty, M. R., 2020. The Implementation Research Logic Model: A Method for Planning, Executing, Reporting and Synthesizing Implementation Projects. Implementation Science, XV(84), pp. 1-12.

Sofaer, S., 2019. Using The Taxonomy and The Metrics: What to Study When and Why. International Journal of Health Policy and Management, VIII(1), pp. 51-54.

Sohrabi, C. et al., 2020. World Health Organization Declares Global Emergency: A Review of The 2019 Novel Coronavirus (COVID-19). International Journal of Surgery, Volume LXXVI, pp. 7176.

W.K. Kellogg Foundation, 2004. Using Logic Models to Bring Together Planning, Evaluation, and Action. Logic Model Development Guide. Michigan: W.K. Kellogg Foundation. 
RSF Conference Series: Medical and Health Science, Vol. 1 (1), 97-105

Factors Influenced Healthcare Service Delivery During COVID-19 Pandemic: A Case Study in Cicalengka, Indonesia Eka Nurhayati, Dika Ananda Elyani, Yanti Fadillah

World Health Organization, 2020. Maintaining Essential Health Services: Operational Guidance for the COVID-19 Context. [Online].[Diakses 2 September 2021]. 